near the lake shore. As they approached the lake it retreated up a mountain path.

The only other record of a wolverine in southern Alberta is that reported by Scotter (1964) for Cardston. Soper (1964) gives Banff as the southern limit of its range and Banfield (1950) does not include the wolverine in his survey of Waterton Lakes National Park.

\section{LITERATURE CITED}

Banfield, A W. F. 1950. The mammals of Waterton Lakes National Park. Canadian Wildlife Service, Wildlife Management Bulletin. Ser. 1, No. 1:54.

Scotter, G. W. 1964. Occurrence of a wolverine in southwestern Alberta. Journal of Mammalogy, $45: 629$.

Smith, H. C. and M. J. Hampson, 1969. A kangaroo rat colony in Alberta. Blue Jay, $27: 224$.

Soper, J. D. 1964. The mammals of Alberta. The Department of Industry and Development Queen's Printer, Edmonton.

\title{
AN OBSERVATION OF APPARENT DEATH-FEIGNING BY A TOAD ${ }^{1}$
}

\section{by Martin K. McNicholl, Department of Zoology, University of Manitoba, Winnipeg ${ }^{2}$}

On July 5, 1970, while paddling a canoe along a ditch in the Delta Marsh, I noticed a small Canadian Toad (Bufo hemiophrys) swimming slowly alongside. I stopped and backed towards the toad, whereupon it swam rapidly for about eight inches and then suddenly flipped over, belly up, with hind-legs folded and fore-legs stretched beyond the head, as if feigning death (Fig. 1). Although I had seen hundreds of toads in the Marsh, none had ever before done this. Usually when encountered, toads either "froze", that is, remained belly down in the water with limbs extended or folded in the position in which they were encountered, or dived. In this case, the toad remained in the "dead" position for about 30 seconds, then righted itself and swam normally. When I again approached the toad, it this time "froze" and then began swimming rapidly. When further pursued, it dived, re-emerged about six inches away, and again "froze". I then picked it up to record its size. After being replaced in the water and again pursued, the toad flipped over onto its back and assumed the same posture described above. Additional attempts to elicit this behaviour, however, were unsuccessful.

\footnotetext{
1 Publication No. 15, University of Manitoba Field Station, Delta, Manitoba.

2 Present address: Department of Zoology,
} University of Alberta, Edmonton, Alberta.
A somewhat similar observation of apparent death-feigning in this species, also in the Delta area, was reported by Nero (1967), and accounts of deathfeigning behaviour in other species of frogs and toads have been reported by Dickerson (1906:71, 87), Noble (1931: 424), and Banta and Carl (1967). Nero (1967) thought such behaviour unusual in this species, and Banta and Carl (1967) referred to it as unusual in Hyla versicolor, the Gray Treefrog. Both Dickerson (1960:71) and Noble (1931:424), however, imply that deathfeigning is easy to elicit in frogs and toads.

Clearly, more observations of this behaviour and the conditions under which it occurs are needed. Several features should be noted:

(1) Size: The toad reported by Nero (op. cit.) was "about an inch long", as was that observed by me. Other reports (Dickerson op. cit.; Noble op. cit.; Sutton, 1961) refer to death-feigning behaviour as occurring particularly in young individuals.

(2) Length of time involved in feint: Noble (op. cit.) stated that the feint "usually lasts only a few minutes, but it may be prolonged over an hour if disturbing sensory impressions are avoided." All other observations cited referred to short time periods (Dickerson op. cit.; Nero op. cit.; Banta and Carl op. cit.; this note). 


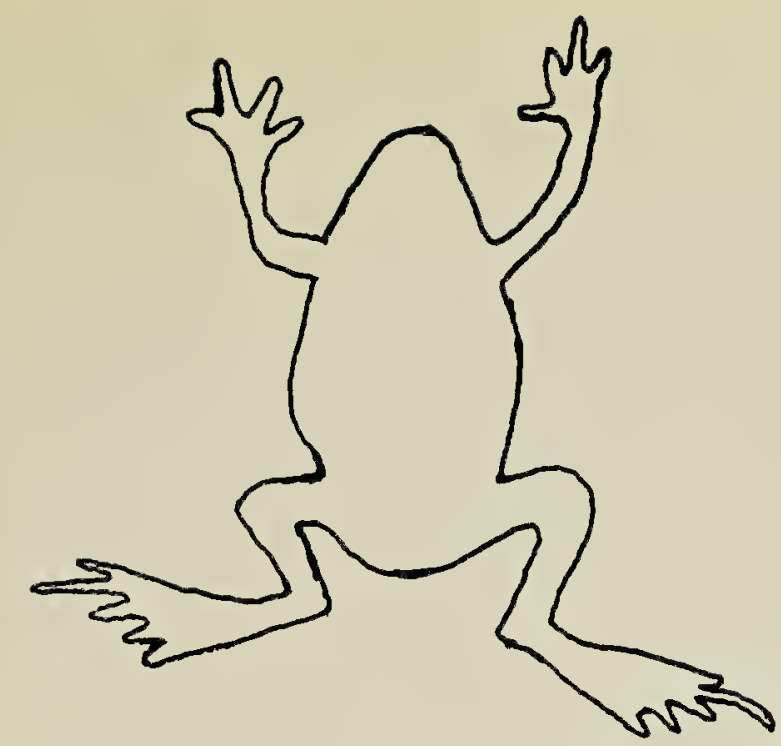

Fig. 1 Posture assumed during "deathfeigning" by a toad at Delta, Manitoba, July 5, 1970.

(3) Location: My observation, and the four observations reported by Banta and Carl (op. cit.), were of toads in water. All other published observations appear to have taken place on land.

(4) Eliciting stimulus: In all reports the toad or frog exhibiting deathfeigning behaviour was either pursued or touched. Most reports state that the individual was picked up or touched (Dickerson 1906:71, 87; Mangold fide Noble 1931:424; Nobleibid; Banta and Carl op. cit.; Nero op. cit.Q, but the toad of my initial observation had not been touched.

(5) Position of limbs: The positions of the limbs vary considerably during death-feigning. All observations or figures indicate that the hind-legs are folded as in Fig. 1 (see Dickerson 1906, fig. 79; Sutton, 1961; Banta and Carl, 1967), except for Nero's (1967) observation in which they "were extended backwards." In most reports the fore-limbs are folded to the sides or partially upwards at the sides (Dickerson 1906, fig. 79; Mangold fide Noble 1931, 424; Sutton 1961; Banta and Carl 1967). In contrast, Nero (1967) observed that the fore-limbs were extended backwards. In the present case they were extended forwards.

(6) Eyes: Sutton (1961) stated that the eyes were open during the death-feint, but both Nero (op. cit.) and I observed them to be closed. Dickerson's (op. cit. :87) statement that "the eyes open wide" on coming out of the death-feint may imply that they were closed or partly closed during the feint, and the eyes appear to be closed in her photo of Bufo fowleri in the feint (op. cit.: fig. 79).

The significance of this behaviour is unknown but it seems likely that it is escape behaviour, as suggested by Dickerson (op. cit.), Banta and Carl (op. cit.), and Nero (op. cit.). This would be effective particularly with predators unwilling or unable to take non-living prey. Observations of a Tiger Salamander (Ambystoma tigrinum) captured at Delta Marsh lend some support to this view. The salamander responded to earthworms or strips of meat only if they moved or were moved. Canadian Toads and Leopard Frogs (Rana pipiens) of small size were eagerly pursued and easily captured. However, one toad which escaped and died after being initially struck by the salamander was left uneaten. These observations are suggestive, but additional work is needed to confirm their significance.

I would like to thank Dr. Roger M. Evans and Dr. Robert W. Nero for assistance in preparing this note. $\mathrm{Mr}$. Francis R. Cook offered useful comments, especially in pointing out the small size of individuals so far reported to exhibit death-feigning.

\section{LITERATURE CITED}

Banta, B. H., and G. Carl. 1967. Deathfeigning behavior in the Eastern Gray Treefrog Hyla versicolor versicolor. Herpetologica $23: 317-318$.

Dickerson, M. C. 1906. The frog book. North American toads and frogs, with a study of the habits and life histories of those of the northeastern states. Doubleday, Page and Co., New York. xxxi+253 pp. (Dover ed., $1969)$.

Nero, R. W. 1967. A possible record of deathfeigning in a toad. Blue Jay 25:193-194.

Noble, G. K. 1931. The biology of the amphibia. McGraw-Hill Book Co., Inc., New York. 577 pp. (Dover ed., 1954).

Sutton, R. W. 1961. Frogs and toads in folklore. Wildlife Notebook, Winnipeg Free Press, June 3, 1961. 